\title{
Renin Inhibitors. II. Synthesis and Structure-Activity Relationships of N-Terminus Modified Inhibitors Containing a Homostatine Analogue ${ }^{1)}$
}

Shugo AtsuUmi, ${ }^{*, a}$ Masato Nakano, ${ }^{a}$ Yutaka KoIKe, ${ }^{a}$ Seiichi TanaKa, ${ }^{a}$ Hiroshi Funabashi, ${ }^{a}$ Kenji MatsuYama, ${ }^{b}$ Makiko NAKANo, ${ }^{b}$ Yoshio SAWASAKI, $^{c}$ Kaoru FunABashi ${ }^{b}$ and Hajime Morishima ${ }^{a}$

Chemistry of Natural Products, Exploratory Research Laboratories, ${ }^{a}$ Biochemistry ${ }^{b}$ and Pharmacology, ${ }^{c}$ Central Research Laboratories, Banyu Pharmaceutical Co., Ltd., 2-9-3, Shimomeguro, Meguro-ku, Tokyo 153, Japan. Received April 23, 1992

The synthesis and structure-activity relationships of $\mathrm{N}$-terminus modified renin inhibitors containing the homostatine analogue, $(2 R S, 4 S, 5 S)$-5-amino-2-ethyl-4-hydroxy-7-methyloctanoic acid, are described. The compounds having a 3-alkyl (or aryl)sulfonylpropionyl residue at the $\mathrm{N}$-terminus are found to be potent inhibitors which contain two amino acids. $(2 R S, 4 S, 5 S)-N$-Isobutyl-5-[N-[(2S)-3-ethylsulfonyl-2-(1-naphthylmethyl)propionyl $]-L-n o r l e u c y l]-$ amino-2-ethyl-4-hydroxy-7-methyloctanamide (20) has an $\mathrm{IC}_{50}$ of $0.5 \mathrm{nM}$ against human plasma renin and the oral bioavailability of 20 is $0.73 \%$ in rats. Interaction between renin and the $\mathrm{N}$-terminus of 1 and 20 is discussed in molecular modeling studies.

Keywords renin inhibitor; antihypertensive agent; homostatine analogue; sulfonemethylene isostere; structure-activity relationship

The renin-angiotensin system plays a central role in the regulation of blood pressure. Renin, an aspartic protease, is the rate limiting enzyme in this cascade and is highly specific for its substrate. Inhibitors of angiotensin converting enzyme, another enzyme of this cascade, are now widely used for hypertensive patients; however adverse effects are observed because of its lower substrate specificity. Therefore, a large number of human renin inhibitors have been investigated as higher quality antihypertensive agents. $^{2)}$ In our preceding paper, compounds 1 and 2 (Fig. 1), which contained the homostatine analogue $(2 R S, 4 S, 5 S)$-5-amino-2-ethyl-4-hydroxy-7-methyloctanoic acid (AEHMA), were shown to be potent renin inhibitors in vitro. ${ }^{1)}$ However, they had low aqueous solubility and low oral bioavailability probably due to their peptidic character (they contained three amino acids). Therefore, in order to overcome these defects, we tried to modify the $\mathrm{N}$-terminal segment of $\mathbf{1}^{3)}$ In this paper, we report the

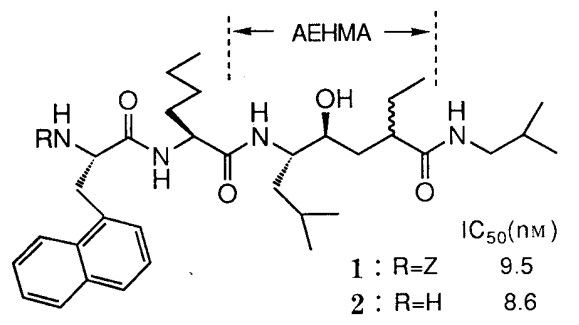

AEHMA : 5-amino-2-ethyl-4-hydroxy-7-methyloctanoic acid

Fig. 1 syntheses and structure-activity relationships of $\mathrm{N}$-terminus modified renin inhibitors which have the homostatine analogue AEHMA. In addition, the computer modeling studies of the interaction between these inhibitors and renin are also described.

Synthesis The compounds prepared for this study are shown in Table I. Syntheses of compounds $5 \mathbf{8}$ are outlined in Chart 1. Z-Nle-AEHMA isobutylamide (4), synthesized by coupling of $\mathrm{Z}-\mathrm{Nle}-\mathrm{OH}$ with AEHMA isobutylamide (3), ${ }^{4)}$ was hydrogenolized and the resulting amine was condensed with 3-(1-naphthyl)propionic acid using diphenyl phosphorazidate (DPPA) to yield 5 in $81 \%$ yield. The reductive alkylation of 2 with formaldehyde or glutaraldehyde using sodium cyanoborohydride $\left(\mathrm{NaBH}_{3} \mathrm{CN}\right)$ in methanol gave 6 or 8 in $86 \%, 45 \%$ yield, respectively. Compound 7 was prepared in a similar manner using benzaldehyde and formaldehyde successively in $88 \%$ yield.

Compounds 11, 12, 14R,S and 17 were prepared from 2ethoxycarbonyl-3-(1-naphthyl)propionic acid (9) as shown in Chart 2. The syntheses of intermediates 10 and $13 R, S$ were described previously. ${ }^{4 a, b}$ ) Deprotection of 10 with trifluoroacetic acid (TFA) followed by coupling with 3 using DPPA gave 11 in $93 \%$ yield. Sodium borohydride $\left(\mathrm{NaBH}_{4}\right)$ reduction of 11 afforded 12 in $92 \%$ yield. After acetylation of $13 R$, deprotection and coupling of the resulting acid with 3 gave $14 R$ in $86 \%$ yield. Compound $14 S$ was prepared from $13 S$ by the same manner in $92 \%$ yield. Compound 17 was obtained from 15 and 16 with DPPA method. Compound 15 was prepared from 9 as

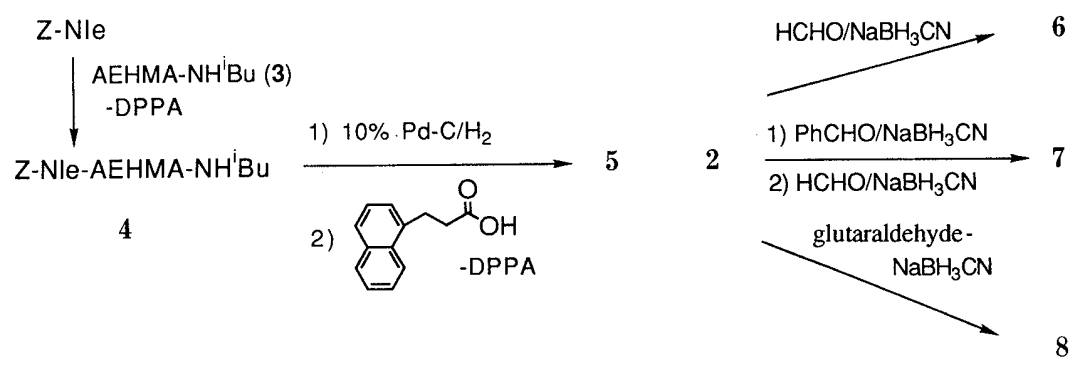

Chart 1 
<smiles>CCOC(=O)CC(C(=O)O)c1cccc2ccccc12</smiles><smiles>CCOC(=O)CCc1cccc2ccccc12</smiles>

1) $\mathrm{LiBH}_{4} / \mathrm{LiOH}$

2) $\mathrm{BzIBr} / \mathrm{NaH}$

3) $\mathrm{KOH}$<smiles>O=C(O)CCCc1cccc2ccccc12</smiles>

15

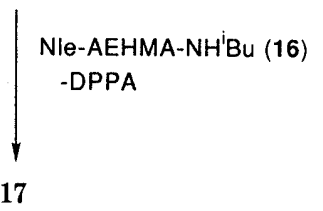<smiles>CCCCOC(=O)C(CCO)Cc1cccc2ccccc12</smiles>

$13 R, S$
2) TFA

3) 3 -DPPA

$14 R, S$
1) $\mathrm{NaBH}_{4}$

2) separation

1) TFA

2) 3 -DPPA

$\mathrm{NaBH}_{4}$

12

Chart 2

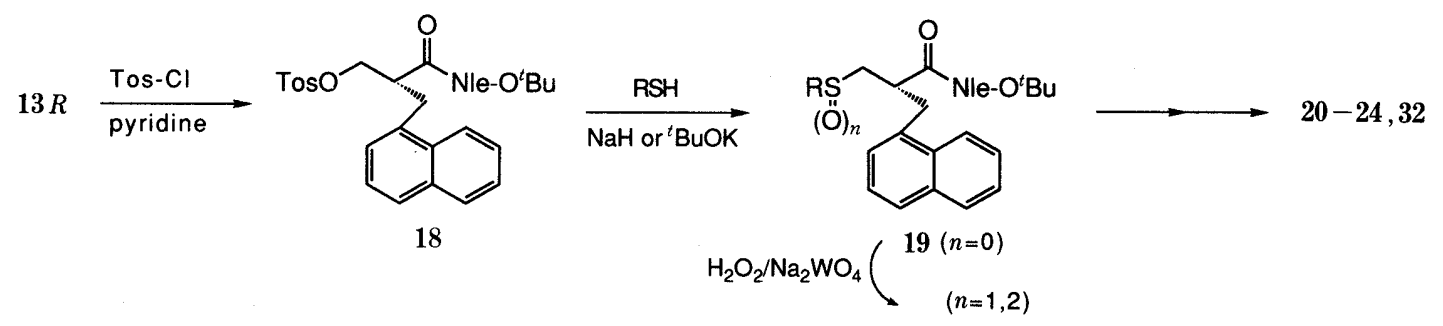

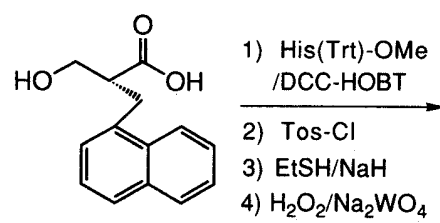

25

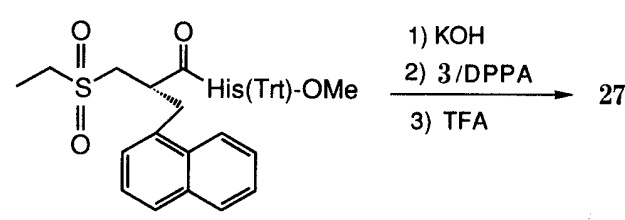

26<smiles>OCC(CO)c1cccc2ccccc12</smiles>

28<smiles>COCC(CO)Cc1cccc2ccccc12</smiles>

29
30

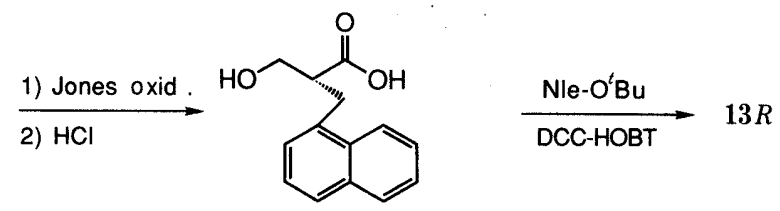

25

Chart 4

follows: 1) selective reduction with lithium borohydride, ${ }^{5)}$ 2) dibenzylation of the hydroxyl and carboxyl groups, and 3 ) hydrolysis of the ester.

The syntheses of compounds $20-24$ and 32 followed the methods described by us previously, ${ }^{4 a, b)}$ and compound 27 was prepared in a similar manner as shown in Chart 3. After (2R)-2-hydroxymethyl-3-(1-naphthyl)propionic acid (25) prepared by the route shown in Chart 4 was condensed with $\mathrm{His}(\mathrm{Trt})-\mathrm{OMe}$ using the dicyclohexylcarbodiimide (DCC)-hydroxybenzotriazole (HOBT) method, 
TABLE I. Structures and Renin Inhibitory Activities

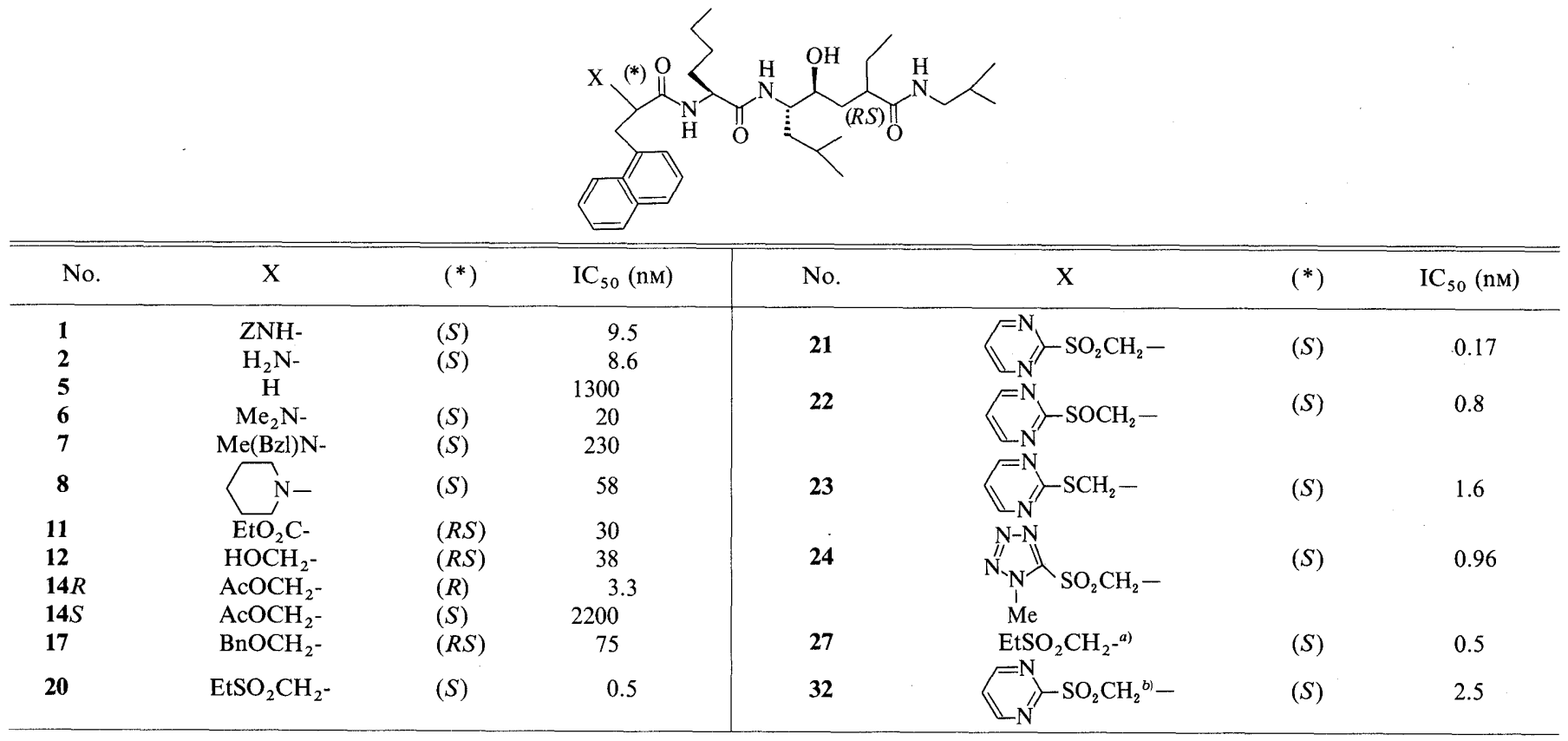

a) $P_{2}$ is His instead of Nle. b) $P_{3}$ is benzyl instead of 1-naphthylmethyl.

tosylation followed by substitution with ethyl mercaptan and oxidation by hydrogen peroxide in the presence of sodium tungstate gave $\mathbf{2 6}$ in $55 \%$ yield from $\mathbf{2 5}$. Hydrolysis of ester 26 followed by coupling of the resulting acid with 3 and deprotection by TFA afforded 27 in $83 \%$ yield from 26.

The stereochemistry of the asymmetric carbon in the propionyl group of $\mathbf{1 4}$ is important for potency against renin, and $R$-configuration is required (compound $14 R$; $3.3 \mathrm{~nm}$ vs. compound $14 S ; 2200 \mathrm{nM}$ ). The $R$-configuration at this position corresponds to the configuration of the L-amino acid. We already reported the enantioselective syntheses of key intermediate 25 by Evans's method ${ }^{4 a, b}$ ) and commercially available lipase. ${ }^{6)}$ In this paper, we described the chemoenzymatic synthesis using lipase $P$ (Chart 4). Mono-acetylation of 2-(1-naphthylmethyl)-1,3propanediol (28), which was prepared from 1-naphthaldehyde and diethyl malonate via 1-naphthylmethylene malonate, catalyzed by lipase $\mathbf{P}$ using vinyl acetate ${ }^{7)}$ as the acyl donor proceeded enantioselectively to afford $(2 R)$ 2-(1-naphthylmethyl)-1,3-propanediol-1-acetate (29) in a $86 \%$ ee and a $93 \%$ chemical yield. ${ }^{8)}$ Treatment of 29 with chloromethyl methyl ether followed by hydrolysis with potassium carbonate gave 30 in $91 \%$ yield. After Jones oxidation of $\mathbf{3 0}$, deprotection with hydrochloric acid afforded crude 25 . A single recrystallization yielded 25 in a $96 \%$ ee and a $50 \%$ chemical yield. ${ }^{9)}$

Structure-Activity Relationships The renin inhibitory potencies of compounds synthesized in this study were measured with human plasma renin by the method described previously, ${ }^{1)}$ and $\mathrm{IC}_{50}$ values are summarized in Table I.

Elimination of the amino group at position 2 of the 3-(1naphthylmethyl)propionic acid residue decreased potency dramatically (compound 2 vs. compound 5). A substituent at this position may be essential for showing inhibitory activity against renin. ${ }^{10)} \mathrm{N}$-Alkylation of 3-(1-naphthyl)-
TABLE II. Characterization of Renin Inhibitors

\begin{tabular}{|c|c|c|c|c|c|}
\hline \multirow{2}{*}{ No. } & \multirow{2}{*}{$t_{\mathrm{R}}(\min )^{a)}$} & \multirow{2}{*}{$\begin{array}{c}\text { Purity } \\
(\%)\end{array}$} & \multirow{2}{*}{ Formula } & \multicolumn{2}{|c|}{$\mathrm{FAB}^{-\mathrm{MS}^{d)}}$} \\
\hline & & & & Calcd & Found \\
\hline 5 & $5.60,5.81$ & 98 & $\mathrm{C}_{34} \mathrm{H}_{53} \mathrm{~N}_{3} \mathrm{O}_{4}$ & 568.4114 & 568.4137 \\
\hline 6 & $5.91,6.28^{b)}$ & 93 & $\mathrm{C}_{36} \mathrm{H}_{59} \mathrm{~N}_{4} \mathrm{O}_{4}$ & 611.4536 & 611.4534 \\
\hline 7 & $9.90,11.08^{b)}$ & 76 & $\mathrm{C}_{42} \mathrm{H}_{62} \mathrm{~N}_{4} \mathrm{O}_{4}$ & 687.4849 & 687.4857 \\
\hline 8 & $8.52,9.40^{b)}$ & 71 & $\mathrm{C}_{39} \mathrm{H}_{62} \mathrm{~N}_{4} \mathrm{O}_{4}$ & 651.4849 & 651.4847 \\
\hline 11 & $\begin{array}{l}6.12,6.45 \\
6.74\end{array}$ & 97 & $\mathrm{C}_{37} \mathrm{H}_{57} \mathrm{~N}_{3} \mathrm{O}_{6}$ & 640.4326 & 640.4314 \\
\hline 12 & $\begin{array}{l}5.16,5.45 \\
5.66,6.02\end{array}$ & 94 & $\mathrm{C}_{35} \mathrm{H}_{55} \mathrm{~N}_{3} \mathrm{O}_{5}$ & 598.4220 & 598.4194 \\
\hline $14 R$ & $5.67,5.99$ & 88 & $\mathrm{C}_{37} \mathrm{H}_{57} \mathrm{~N}_{3} \mathrm{O}_{6}$ & 640.4326 & 640.4305 \\
\hline $14 S$ & $6.06,6.32$ & 87 & $\mathrm{C}_{37} \mathrm{H}_{57} \mathrm{~N}_{3} \mathrm{O}_{6}$ & 640.4326 & 640.4314 \\
\hline 17 & $8.89,9.56$ & 86 & $\mathrm{C}_{42} \mathrm{H}_{61} \mathrm{~N}_{3} \mathrm{O}_{5}$ & 688.4690 & 688.4714 \\
\hline 20 & $4.76,5.00$ & 95 & $\mathrm{C}_{37} \mathrm{H}_{59} \mathrm{~N}_{3} \mathrm{O}_{6} \mathrm{~S}$ & 674.4203 & 674.4217 \\
\hline 21 & $6.42,6.77$ & 88 & $\mathrm{C}_{39} \mathrm{H}_{57} \mathrm{~N}_{5} \mathrm{O}_{4} \mathrm{~S}$ & 692.4210 & 692.4214 \\
\hline 22 & $4.88,5.18$ & 93 & $\mathrm{C}_{39} \mathrm{H}_{57} \mathrm{~N}_{5} \mathrm{O}_{5} \mathrm{~S}$ & 708.4159 & 708.4151 \\
\hline 23 & $4.56,4.78$ & 94 & $\mathrm{C}_{39} \mathrm{H}_{57} \mathrm{~N}_{5} \mathrm{O}_{6} \mathrm{~S}$ & 724.4108 & 724.4100 \\
\hline 24 & $5.06,5.34$ & 77 & $\mathrm{C}_{37} \mathrm{H}_{57} \mathrm{~N}_{7} \mathrm{O}_{6} \mathrm{~S}$ & 728.4169 & 728.4171 \\
\hline 27 & $4.95,5.00^{c)}$ & 88 & $\mathrm{C}_{37} \mathrm{H}_{55} \mathrm{~N}_{5} \mathrm{O}_{6} \mathrm{~S}$ & 698.3951 & 698.3962 \\
\hline 32 & 4.08 & 97 & $\mathrm{C}_{35} \mathrm{H}_{55} \mathrm{~N}_{5} \mathrm{O}_{6} \mathrm{~S}$ & 674.3951 & 674.3959 \\
\hline
\end{tabular}

a) See the experimental section for conditions. b) Solvent, $\mathrm{MeOH}: 10 \mathrm{~mm}$ $\mathrm{AcONH}_{4}=7: 1$. c) Solvent, $\mathrm{MeOH}: 10 \mathrm{~mm} \mathrm{AcONH} 4=5: 1$. d) For $[\mathrm{M}+$ $\mathrm{H}]^{+}$.

alanine in $\mathbf{2}$ also caused the loss of potency (compounds 6 -8), especially in compound 7 which was 26-fold less potent than 2. Compound 6 was stable in rat liver homogenate and had improved aqueous solubility $(43.7 \mu \mathrm{g} / \mathrm{ml}$ in saline, Table IV). However, in our in vivo study on the metabolic fate of 6 using ${ }^{13} \mathrm{C}$-labeled compound, the $N$-methyl group was oxidized and excreted in expired air as carbon dioxide. ${ }^{11)}$ Therefore, further investigation at $\mathrm{N}$-terminus was carried out. Replacement of the amino group in $\mathbf{2}$ with an ethoxycarbonyl group or a hydroxymethyl group slightly decreased potency (compounds 11 and 12). Although acetylation of 12 gave 
a more potent inhibitor (compound 14R), benzylation afforded a 2 -fold decrease in potency (compound 17). The result suggested that the carbonyl of the acetyl group in $\mathbf{1 4}$ formed a hydrogen bond with the enzyme. Replacement of the 2(R)-3-acetoxypropionyl group with $2(S)$-isomer abolished activity (compound 14S). Substitution of the acetoxy group in $14 R$ with the ethylsulfonyl group, which was thought to form a hydrogen bond with the enzyme like the acetoxy group, afforded a 6-fold increase in potency (compound 20). ${ }^{12)}$ Furthermore, replacement of the ethyl group in $\mathbf{2 0}$ with the 2-pyrimidinyl group gave the most potent inhibitor in this study (compound 21, $\left.\mathrm{IC}_{50}: 0.17 \mathrm{~nm}\right)$. The corresponding sulfoxide (22) and sulfide (23) were less potent than the sulfone. The com- pound containing histidine at $\mathrm{P}_{2}$ instead of norleucine was equipotent (compound 20 vs. compound 27). Substitution of the naphthylmethyl group at $\mathbf{P}_{3}$ with the benzyl group gave a 15-fold decrease in potency (compound $\mathbf{2 1}$ vs. compound 32). This result was consistent with that reported previously. ${ }^{1)}$

Modeling Studies Although the three dimensional structure of renin $^{13)}$ or renin and its inhibitors ${ }^{14)}$ were investigated by X-ray analysis, the coordinate data have not yet been shown. To investigate the interaction between renin and its inhibitors, we constructed a model of renin referring to the $\mathrm{X}$-ray structure of pepsin ${ }^{15}$ ) which has better sequence homology to renin than any other aspartic proteinases, by virtue of BIOCES[E], ${ }^{16)}$ a computer aided

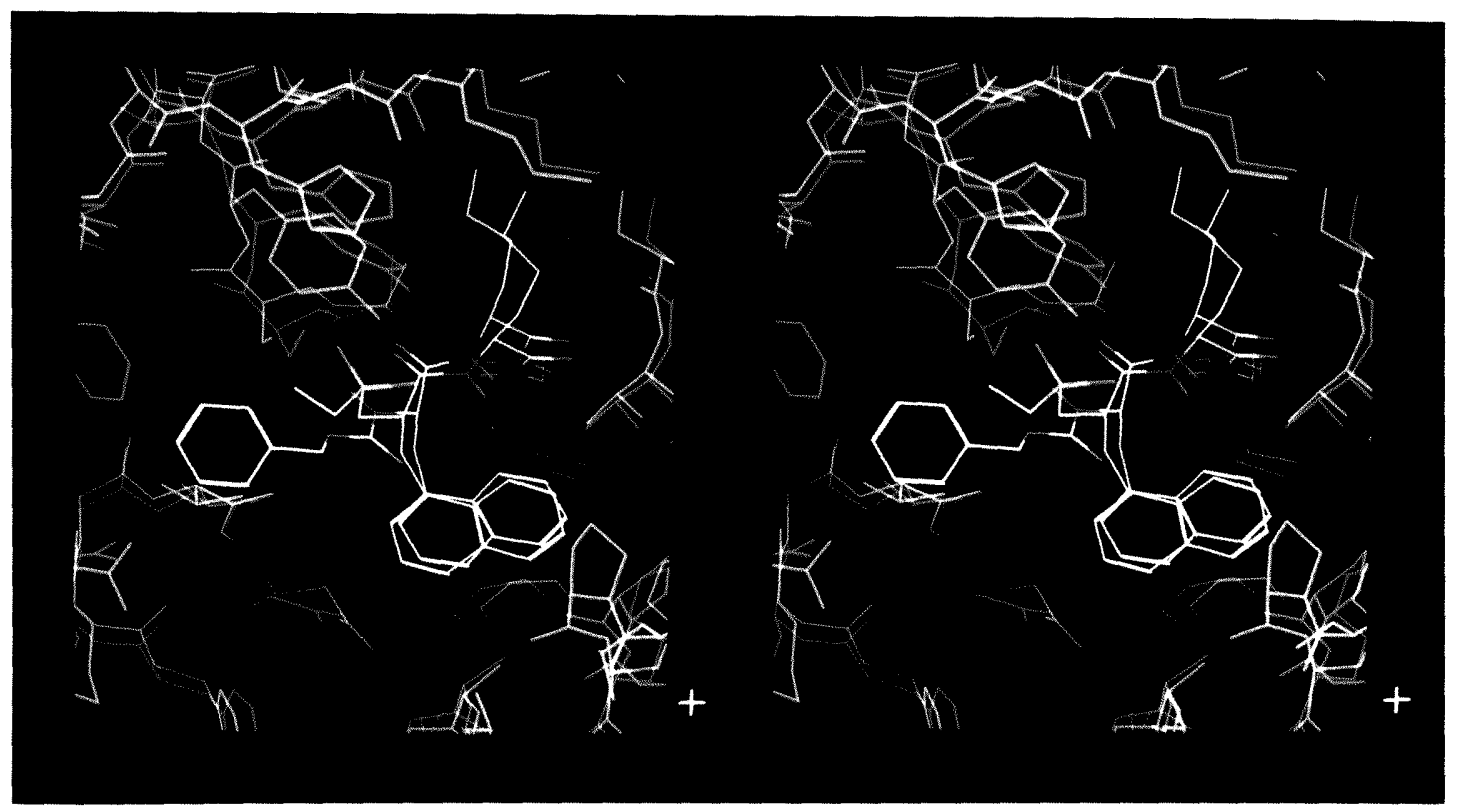

Fig. 2. Stereo View of $\mathbf{1}$ with Renin (Yellow) and $\mathbf{2 0}$ with Renin (Cyan)

Inhibitors are colored as follows; carbon (white), oxygen (red), nitrogen (blue), sulfur (yellow).
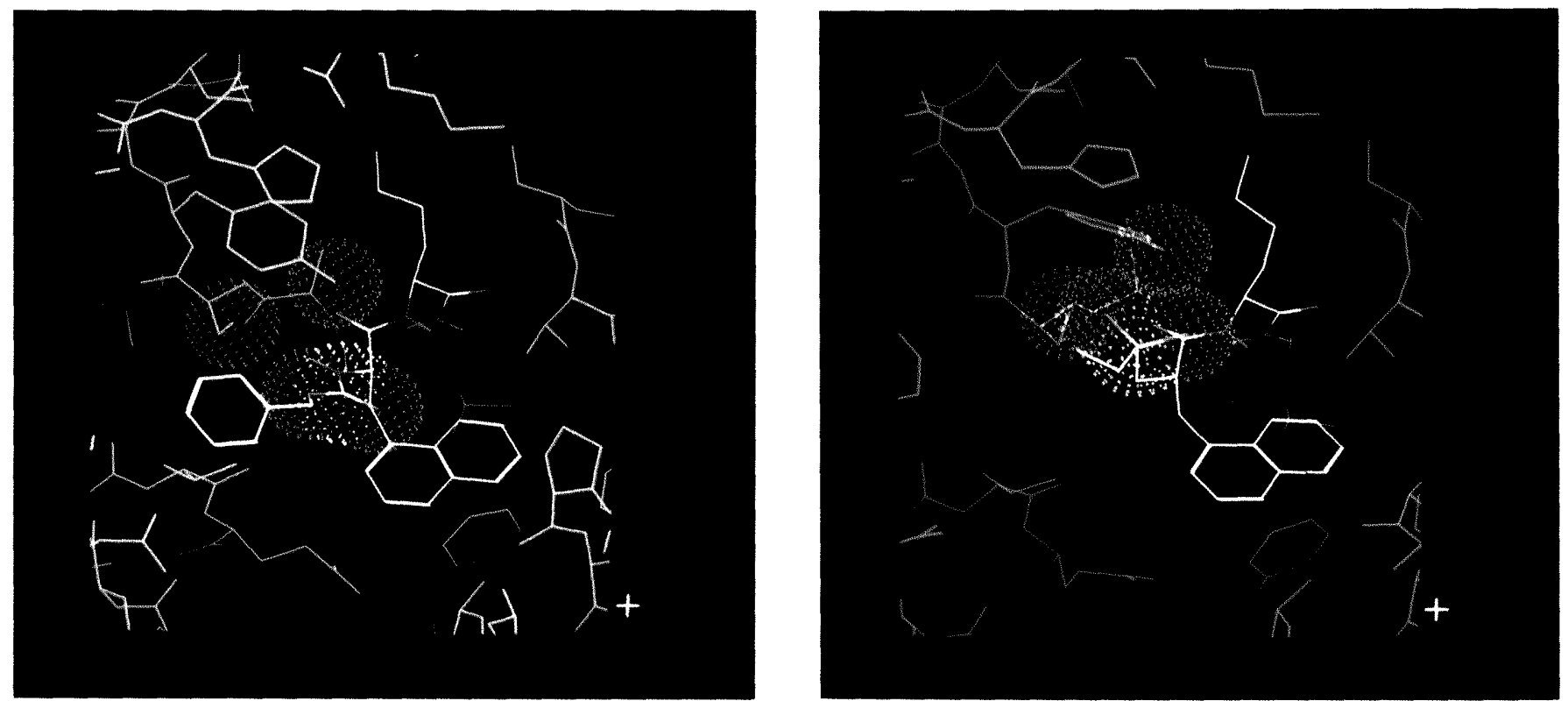

Fig. 3. Dot-Surface Display of Van Der Waals Radii of Atoms around N-Terminus of 1 (Left) or 20 (Right)

Atoms are colored as follows; oxygen (red), carbon (white), sulfur (yellow). 


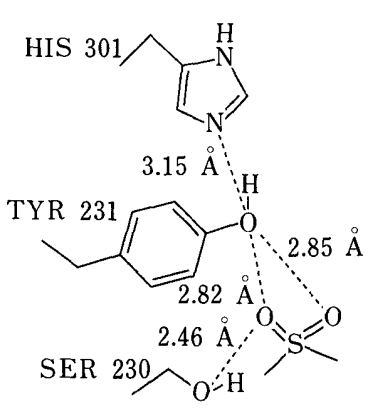

Fig. 4. Schematic Representation of Distances between the Sulfonyl Group of $\mathbf{2 0}$ and Surrounding Residues of Renin

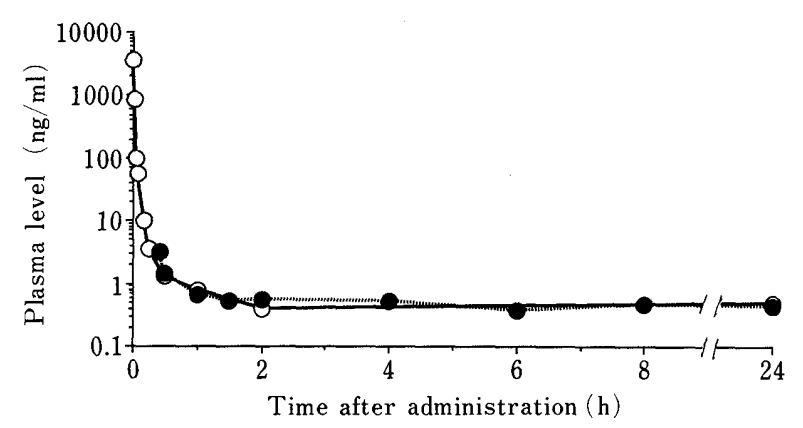

Fig. 5. Plasma Levels of Compound $\mathbf{2 0}$ in Rats after Administrations of $0.35 \mathrm{mg} / \mathrm{kg}$ i.v. (-O-) and $8.4 \mathrm{mg} / \mathrm{kg}$ p.o. (--- ---)

Blood samples were collected at $20 \mathrm{~s}, 1,3,5,10,15,30 \mathrm{~min}, 1,2$, and $24 \mathrm{~h}$ (i.v.), and $15,30 \mathrm{~min}, 1,1.5,2,4,6,8$, and $24 \mathrm{~h}$ (p.o.).

modeling system. Docking of an inhibitor to the model enzyme was proceeded by referring to the structure of the rhizopuspepsin-inhibitor complex. ${ }^{17)}$ The modeled enzyme was superimposed on rhizopuspepsin and then inhibitor 20 was fitted onto the inhibitor of rhizopuspepsin. Inhibitor 1 was treated as in the same way. The enzyme-inhibitor complexes were energetically minimized and subjected to analysis on graphic display.

Comparison of the complex structures of $\mathbf{1}$ and renin or 20 and renin shows a fairly good overlap of the two inhibitors except at the N-termini (Fig. 2). In the case of 20, sulfonyl group gains good van der Waals contact with side chains of $\operatorname{Ser}^{230}$ and $\mathrm{Tyr}^{231}$, while the oxycarbonyl group of 1 cannot make favorable interactions with those residues (Fig. 3). One of the sulfonyl oxygens of $\mathbf{2 0}$ may form a hydrogen bond with the hydroxyl group of $\mathrm{Ser}^{230}$ as the distance between the two oxygen atoms is suitable for hydrogen bonding and the hydrogen is in a favorable direction (Fig. 4). However, the hydroxyl group of $\mathrm{Tyr}^{231}$ may not form a hydrogen bond with the sulfonyl oxygen of $\mathbf{2 0}$ because the hydrogen atom of the hydroxyl group of Try $^{231}$ points to $\mathrm{N}^{\varepsilon 2}$ of $\mathrm{His}^{301}$, although the hydroxyl oxygen of $\mathrm{Tyr}^{231}$ and the oxygen atom of the sulfonyl group are in favorable distance for hydrogen bonding.

The result of the modeling studies is consistent with the experimental data of $\mathrm{IC}_{50}$ values (Table I). Modification of $\mathbf{N}$-terminus of $\mathbf{1}$ with the ethylsulfonyl group could bring about better van der Waals contact and hydrogen bonding interactions, so that $\mathbf{2 0}$ could show 20 -fold more potent inhibitory activity than $\mathbf{1}$.

Enzyme Specificity and Aqueous Solubility High enzyme specificity is a factor for more useful renin inhibitors. Compounds 20 and 21 inhibited cathepsin D and pepsin as
TABLE III. Enzyme Specificity

\begin{tabular}{cccc}
\hline No. & $\begin{array}{c}\text { Renin } \\
\text { (Human) }\end{array}$ & $\begin{array}{c}\mathrm{IC}_{50}(\mathrm{nM}) \\
\text { Cathepsin } \\
\text { (Bovine) }\end{array}$ & $\begin{array}{c}\text { Pepsin } \\
\text { (Porcine) }\end{array}$ \\
\hline $\mathbf{2 0}$ & 0.50 & 15 & 260 \\
$\mathbf{2 1}$ & 0.17 & 16 & 230 \\
$\mathbf{2 7}$ & 0.50 & 8500 & $(25 \%$ at $100 \mu \mathrm{M})$ \\
\hline
\end{tabular}

TABLE IV. Aqueous Solubility

\begin{tabular}{rc} 
No. & Solubility $(\mu \mathrm{g} / \mathrm{ml} \text { in saline })^{a)}$ \\
\hline 1 & $<0.07$ \\
6 & $43.7^{b)}$ \\
20 & 0.37 \\
21 & 0.09 \\
\hline
\end{tabular}

a) Determined by enzyme inhibition assay, b) $\mathrm{HCl}$ salt.

well as renin, however compound 27 containing histidine at $\mathrm{P}_{2}$ had good selectivity for renin (Table III). This result was consistent with that reported by the Kissei group ${ }^{18)}$ and Abbott group. ${ }^{19)}$

Aqueous solubilities were determined for inhibitors $\mathbf{6}$, 20 and 21 (Table IV). Compound 6 was considerably, and compounds 20 and 21 were slightly, more soluble than the lead compound $\mathbf{1}$.

Oral Bioavailability of Inhibitor 20 in Rats In order to determine the oral bioavailability of $\mathbf{2 0}$ in rats, preliminary experiments $(n=2)$ were carried out (Fig. 5). We selected compound $\mathbf{2 0}$ because it was superior in terms of ease of synthesis and His of compound 27 was thought to augment biliary excretion and adversely affect oral absorption. ${ }^{19)}$ The compound was dissolved in dimethyl sulfoxide (DMSO)/saline or DMSO/water and was administered to conscious, fed rats either intravenously (i.v.) or orally (p.o.). Plasma levels of $\mathbf{2 0}$ were determined by enzyme inhibition assay after extraction with methanol. After an i.v. dose of $0.35 \mathrm{mg} / \mathrm{kg}$ of $\mathbf{2 0}$, the plasma level was $3506.7 \pm 195.8 \mathrm{ng} / \mathrm{ml}$ at $20 \mathrm{~s}$, followed by $101.3 \pm 6.5 \mathrm{ng} / \mathrm{ml}$ at $3 \mathrm{~min}$ and $3.7 \pm 0.1 \mathrm{ng} / \mathrm{ml}$ at $15 \mathrm{~min}$. About $99 \%$ of the initial dose was eliminated from circulation within the first $15 \mathrm{~min}\left(t_{1 / 2}: 1.5 \mathrm{~min}\right)$. When given orally, a maximum plasma level of $3.20 \pm 1.40 \mathrm{ng} / \mathrm{ml}$ was observed at $15 \mathrm{~min}$ at a dose of $8.4 \mathrm{mg} / \mathrm{kg}$. Plasma levels fell rapidly by $1 \mathrm{~h}$ $(0.66 \pm 0.22 \mathrm{ng} / \mathrm{ml})\left(t_{1 / 2}: 21 \mathrm{~min}\right)$. Values of $\mathrm{AUC}_{0-24}$ at $0.35 \mathrm{mg} / \mathrm{kg}$ i.v. and $8.4 \mathrm{mg} / \mathrm{kg}$ p.o. were $67.9 \pm 0.3$ and $11.9 \pm 0.5 \mathrm{ng} \cdot \mathrm{h} / \mathrm{ml}$, respectively, and the oral bioavailability was calculated as $0.73 \%$.

\section{Conclusion}

Structure-activity studies directed toward improving the aqueous solubility and the oral bioavailability of starting compound 1 led to compound 20. Although compound $\mathbf{2 0}$ was a potent renin inhibitor in vitro, its oral bioavailability was still poor. Modification of the physicochemical properties of $\mathbf{2 0}$ were required to achieve the desired profile. Further investigation is in progress.

\footnotetext{
Experimental

Melting points were determined with a Yanagimoto melting point apparatus and uncorrected. Infrared (IR) spectra were measured with a
} 
Hitachi 270-30 infrared spectrophotometer. Proton nuclear magnetic resonance $\left({ }^{1} \mathrm{H}-\mathrm{NMR}, 300 \mathrm{MHz}\right)$ spectra were recorded with a Varian VXR-300 spectrometer in deuteriochloroform $\left(\mathrm{CDCl}_{3}\right)$. Chemical shifts are reported relative to residual protons of deuterated NMR solvents Fast atom bombardment mass spectra (FAB-MS) were obtained with a JEOL JMS-DX 300 mass spectrometer. Optical rotations were determined with a Horiba SEPA-200 high-sensitivity polarimeter. Analytical high-performance liquid chromatography (HPLC) was carried out on Hitachi L-6200 system, using packed column Inertsil ODS $(5 \mu \mathrm{m}$ $4.6 \times 250 \mathrm{~mm})$, and $\mathrm{MeOH}$-water $(90: 10)$ elutions unless otherwise stated (flow rate, $1 \mathrm{ml} / \mathrm{min}$ ), with ultraviolet (UV) detection at $254 \mathrm{~nm}$ (Hitachi L-4000 UV detector). Column chromatography was done on Kieselgel 60 (E. Merck, 70-230 mesh). The organic solutions were dried over $\mathrm{MgSO}$ before vacuum evaporation.

$(2 R S, 4 S, 5 S)-N$-Isobutyl-5-[ $N$-[3-(1-naphthyl)propionyl]-L-norleucyl $]$ amino-2-ethyl-4-hydroxy-7-methyloctanamide (5) To a solution of $N$ benzyloxycarbonyl-L-norleucine $(100 \mathrm{mg}, 0.38 \mathrm{mmol}$ ), AEHMA isobutylamide (3) hydrochloride $(105 \mathrm{mg}, 0.34 \mathrm{mmol})$ and DPPA (54 mg, $0.41 \mathrm{mmol}$ ) in dimethylformamide (DMF, $1 \mathrm{ml}$ ) was added triethylamine $\left(41 \mathrm{mg}, 0.85 \mathrm{mmol}\right.$ ) at $-10^{\circ} \mathrm{C}$. The mixture was stirred for $2 \mathrm{~h}$ at $-10^{\circ} \mathrm{C}$ and further stirred at room temperature overnight. The reaction mixture was diluted with AcOEt and washed with $1 \mathrm{~N} \mathrm{HCl}$, saturated $\mathrm{NaHCO}_{3}$, water and brine. Drying followed by evaporation and purification by silica gel chromatography $\left(\mathrm{CHCl}_{3}: \mathrm{MeOH}=100: 1\right)$ afforded 4 as a colorless powder in $69.2 \%$ yield, $\mathrm{mp} 160.0-163.0^{\circ} \mathrm{C},[\alpha]_{\mathrm{D}}^{20}-18.6^{\circ}$ $\left(c=1.02, \mathrm{CHCl}_{3}\right)$. IR (KBr): 3316, $1713,1647 \mathrm{~cm}^{-1} .{ }^{1} \mathrm{H}-\mathrm{NMR}\left(\mathrm{CDCl}_{3}\right)$ $\delta: 0.78-1.00(18 \mathrm{H}, \mathrm{m}), 1.15-1.92(14 \mathrm{H}, \mathrm{m}), 2.13-2.35(1 \mathrm{H}, \mathrm{m})$, $2.93-3.20(5 / 2 \mathrm{H}, \mathrm{m}), 3.55-3.70(1 \mathrm{H}, \mathrm{m}), 3.78-4.04(3 / 2 \mathrm{H}, \mathrm{m}), 4.04$ $4.17(1 \mathrm{H}, \mathrm{m}), 5.10(2 \mathrm{H}, \mathrm{s}), 5.15-5.32(1 \mathrm{H}, \mathrm{br}), 5.72-5.85(1 \mathrm{H}, \mathrm{m})$, 6.05-6.20 (1H, br), 7.22-7.42 (5H, m). FAB-MS $m / z:[\mathrm{M}+\mathrm{H}]^{+}$Calcd for $\mathrm{C}_{29} \mathrm{H}_{50} \mathrm{~N}_{3} \mathrm{O}_{5}$ : 520.3751 . Found: 520.3746

A suspension of $4(40 \mathrm{mg}, 0.077 \mathrm{mmol})$ and $10 \% \mathrm{Pd}-\mathrm{C}(20 \mathrm{mg})$ in $\mathrm{EtOH}(2 \mathrm{ml})$ was stirred under hydrogen atmosphere for $2 \mathrm{~h}$ at room temperature. The catalyst was filtered off and the filtrate was concentrated. The residue was dissolved in DMF $(1 \mathrm{ml})$, and then 3-(1naphthyl)propionic acid $(17 \mathrm{mg}, 0.111 \mathrm{mmol})$ were added at $-10^{\circ} \mathrm{C}$ Compound $\mathbf{5}$ was prepared by a procedure similar to that described for 4, and was chromatographed on silica gel with $\mathrm{CHCl}_{3}-\mathrm{MeOH}(100: 1)$; $81.2 \%$ yield as a colorless solid, mp $188.0-191.0^{\circ} \mathrm{C} .{ }^{1} \mathrm{H}-\mathrm{NMR}\left(\mathrm{CDCl}_{3}\right)$ $\delta: 0.78-1.04(18 \mathrm{H}, \mathrm{m}), 1.04-1.90(14 \mathrm{H}, \mathrm{m}), 2.14-2.26(\mathrm{l} / 2 \mathrm{H}, \mathrm{m})$, $2.26-2.39(1 / 2 \mathrm{H}, \mathrm{m}), 2.55-2.70(2 \mathrm{H}, \mathrm{m}), 2.95-3.20(2 \mathrm{H}, \mathrm{m}), 3.30$ $(1 / 2 \mathrm{H}$, brd,$J=3.1 \mathrm{~Hz}), 3.33-3.49(2 \mathrm{H}, \mathrm{m}), 3.52-3.68(1 \mathrm{H}, \mathrm{m}), 3.78$ $3.97(\mathrm{lH}, \mathrm{m}), 4.24(\mathrm{l} / 2 \mathrm{H}, \mathrm{m}), 4.32-4.44(1 \mathrm{H}, \mathrm{m}), 5.68(1 / 2 \mathrm{H}, \mathrm{t}$, $J=5.4 \mathrm{~Hz}), 5.98(1 / 2 \mathrm{H}, \mathrm{d}, J=9.5 \mathrm{~Hz}), 7.28-7.42(2 \mathrm{H}, \mathrm{m}), 7.42-7.56$ $(2 \mathrm{H}, \mathrm{m}), 7.72(1 \mathrm{H}, \mathrm{d}, J=7.8 \mathrm{~Hz}), 7.85(1 \mathrm{H}, \mathrm{m}), 8.02(1 \mathrm{H}, \mathrm{t}, J=8.0 \mathrm{~Hz})$

$(2 R S, 4 S, 5 S)-N$-Isobutyl-5-[ $N$-[ $N, N$-dimethyl-3-(1-naphthyl)-L-alanyl $]$ L-norleucyl] amino-2-ethyl-4-hydroxy-7-methyloctanamide (6) A solution of $2(6.6 \mathrm{mg}, 0.011 \mathrm{mmol})$, and formaldehyde $(33 \%$ solution in water, $4.0 \mu \mathrm{l}, 0.053 \mathrm{mmol})$ in $\mathrm{MeOH}(0.3 \mathrm{ml})$ was acidified with $0.1 \mathrm{~N} \mathrm{HCl}$ to $\mathrm{pH}$ 4 and a solution of sodium cyanoborohydride $(3.4 \mathrm{mg}, 0.055 \mathrm{mmol})$ in $\mathrm{MeOH}(0.2 \mathrm{ml})$ was added. The mixture was stirred for $3 \mathrm{~h}$ at room temperature and acidified to $\mathrm{pH} 2$ with $50 \%$ acetic acid. The resulting mixture was adjusted to $\mathrm{pH} 9$ with saturated $\mathrm{NaHCO}_{3}$ and extracted with AcOEt. The organic layer was washed with saturated $\mathrm{NaHCO}_{3}$, water and brine. Drying and evaporation gave $6(5.6 \mathrm{mg}, 86.0 \%)$. Compound 6 was used as a hydrochloride salt prepared by treatment with $1 \mathrm{~N} \mathrm{HCl}(1 \mathrm{eq})$ in $\mathrm{MeOH}$ and evaporation, $\mathrm{mp} 125.0-127.0^{\circ} \mathrm{C}$. ${ }^{1} \mathrm{H}-\mathrm{NMR}\left(\mathrm{CDCl}_{3}\right) \quad \delta: 0.68-0.92(15 \mathrm{H}, \mathrm{m}), 1.07-1.90(17 \mathrm{H}, \mathrm{m})$, $2.05-2.38(7 \mathrm{H}, \mathrm{m}), 2.93(2 \mathrm{H}, \mathrm{m}), 3.05(1 \mathrm{H}, \mathrm{m}), 3.35(\mathrm{lH}, \mathrm{m}), 3.45-3.60$ $(2 \mathrm{H}, \mathrm{m}), 3.80(1 \mathrm{H}, \mathrm{m}), 4.24(1 \mathrm{H}, \mathrm{m}), 7.21-7.52(4 \mathrm{H}, \mathrm{m}), 7.60-7.85(2 \mathrm{H}$, $\mathrm{m}), 8.05(1 \mathrm{H}, \mathrm{m})$.

$(2 R S, 4 S, 5 S)-N$-Isobutyl-5-[ $N$-[ $N$-benzyl- $N$-methyl-3-(1-naphthyl)-Lalanyl]-L-norleucyl] amino-2-ethyl-4-hydroxy-7-methyloctanamide (7) A solution of $2(17.7 \mathrm{mg}, 0.030 \mathrm{mmol})$ and benzaldehyde $(16.1 \mathrm{mg}, 0.15 \mathrm{mmol})$ in $\mathrm{MeOH}(0.5 \mathrm{ml})$ was acidified with $0.1 \mathrm{~N} \mathrm{HCl}$ to $\mathrm{pH} 4$, and then a solution of $\mathrm{NaBH}_{3} \mathrm{CN}(9.5 \mathrm{mg}, 0.15 \mathrm{mmol})$ in $\mathrm{MeOH}(0.2 \mathrm{ml})$ was added. The same manner described for 6 gave $N$-benzyl derivative $(16.8 \mathrm{mg}$, $82.1 \%$ ) of 2 . The title compound was prepared from $N$-benzyl compound ( $7.4 \mathrm{mg}, 0.01 \mathrm{mmol})$ and formaldehyde $(4 \mathrm{ml}, 0.05 \mathrm{mmol})$ with $\mathrm{NaBH}_{3} \mathrm{CN}$ $(3.6 \mathrm{mg}, 0.06 \mathrm{mmol})$ by a procedure similar to that described for 6 ; yield $7.6 \mathrm{mg}$ (quant.) as a hydrochloride salt, $\mathrm{mp} 109.0-114.0^{\circ} \mathrm{C}$. ${ }^{1} \mathrm{H}-\mathrm{NMR}$ $\left(\mathrm{CD}_{3} \mathrm{OD}\right) \delta: 0.65-1.10(18 \mathrm{H}, \mathrm{m}), 1.10-1.95(14 \mathrm{H}, \mathrm{m}), 2.19(1 / 2 \mathrm{H}, \mathrm{m})$, $2.37(1 / 2 \mathrm{H}, \mathrm{m}), 2.65-3.12(5 \mathrm{H}, \mathrm{m}), 3.35-4.65(8 \mathrm{H}, \mathrm{m}), 7.28-7.65(9 \mathrm{H}$, $\mathrm{m}), 7.78-7.98(2 \mathrm{H}, \mathrm{m}), 8.02(1 / 2 \mathrm{H}, \mathrm{m}), 8.12(1 / 2 \mathrm{H}, \mathrm{m})$

(2RS,4S,5S)- $N$-Isobutyl-5-[N-[(2S)-3-(1-naphthyl)-2-piperidinopropio-
nyl]-L-norleucyl]amino-2-ethyl-4-hydroxy-7-methyloctanamide (8) The title compound was prepared from $2(100 \mathrm{mg}, 0.172 \mathrm{mmol})$, glutaraldehyde $(25 \%$ solution in water, $68 \mu \mathrm{l}, 0.172 \mathrm{mmol})$, and $\mathrm{NaBH}_{3} \mathrm{CN}$ (76 $\mathrm{mg}, 1.20 \mathrm{mmol}$ ) by a procedure similar to that described for 6 , and was chromatographed on silica gel with $\mathrm{CHCl}_{3}-\mathrm{MeOH}(40: 1)$; yield $75.2 \mathrm{mg}(70.2 \%)$. It was used as a hydrochloride salt, $\mathrm{mp} 114.0$ $118.0^{\circ} \mathrm{C} .{ }^{1} \mathrm{H}-\mathrm{NMR}\left(\mathrm{CDCl}_{3}\right) \delta: 0.78-1.02(18 \mathrm{H}, \mathrm{m}), 1.10-2.10(20 \mathrm{H}$, $\mathrm{m}), 2.23(1 \mathrm{H}, \mathrm{m}), 2.47-2.75(3 \mathrm{H}, \mathrm{m}), 2.80-3.50(4 \mathrm{H}, \mathrm{m}), 3.50-4.00$ $(5 \mathrm{H}, \mathrm{m}), 4.30(1 \mathrm{H}, \mathrm{m}), 5.76(1 / 2 \mathrm{H}, \mathrm{t}, J=7.2 \mathrm{~Hz}), 5.97(1 / 2 \mathrm{H}, \mathrm{br}), 6.38$ $(1 / 2 \mathrm{H}, \mathrm{d}, J=8.3 \mathrm{~Hz}), 6.75(1 / 2 \mathrm{H}, \mathrm{d}, J=9.0 \mathrm{~Hz}), 7.10-7.60(4 \mathrm{H}, \mathrm{m}), 7.70$ $(1 \mathrm{H}, \mathrm{m}), 7.85(1 \mathrm{H}, \mathrm{m}), 8.08(1 / 2 \mathrm{H}, \mathrm{m}), 8.16(1 / 2 \mathrm{H}, \mathrm{m})$.

$(2 R S, 4 S, 5 S)-N$-Isobutyl-5-[ $N$-[ $(2 R S)-2$-ethoxycarbonyl-3-(1-naphthyl)propionyl]-L-norleucyl] amino-2-ethyl-4-hydroxy-7-methyloctanamide (11) To a solution of $10(51.6 \mathrm{mg}, 0.117 \mathrm{mmol})$ in $\mathrm{CH}_{2} \mathrm{Cl}_{2}(0.4 \mathrm{ml})$ was added TFA $(0.4 \mathrm{ml})$. The solution was stirred for $2 \mathrm{~h}$ at room temperature and evaporated. The residue was dissolved in DMF $(0.5 \mathrm{ml})$, and then triethylamine $(33 \mu \mathrm{l}, 0.24 \mathrm{mmol})$, DPPA $(33 \mu 1,0.15 \mathrm{mmol})$ and a solution of AEHMA isobutylamide hydrochloride $(54 \mathrm{mg}, 0.18 \mathrm{mmol})$ in DMF $(0.8 \mathrm{ml})$ were added at $-10^{\circ} \mathrm{C}$. The mixture was stirred for $1 \mathrm{~h}$ at $-10^{\circ} \mathrm{C}$ and further stirred at $5^{\circ} \mathrm{C}$ overnight. The mixture was diluted with AcOEt and washed with $5 \% \mathrm{KHSO}_{4}, 4 \% \mathrm{NaHCO}_{3}$ and brine. Drying followed by evaporation and purification by flash chromatography $\left(\mathrm{CHCl}_{3}: \mathrm{MeOH}=100: 1\right)$ afforded $11(69.7 \mathrm{mg}, 93.3 \%)$ as a colorless solid, mp 143.0-147.0 ${ }^{\circ} \mathrm{C}$. ${ }^{1} \mathrm{H}-\mathrm{NMR}\left(\mathrm{CDCl}_{3}\right) \delta: 0.70-1.95(35 \mathrm{H}, \mathrm{m})$, $2.20(1 / 2 \mathrm{H}, \mathrm{m}), 2.29(1 / 2 \mathrm{H}, \mathrm{m}), 2.88-3.20(3 \mathrm{H}, \mathrm{m}), 3.55-3.99(5 \mathrm{H}, \mathrm{m})$, $4.10(2 \mathrm{H}, \mathrm{m}), 4.29(1 \mathrm{H}, \mathrm{m}), 7.30-7.42(2 \mathrm{H}, \mathrm{m}), 7.45-7.60(2 \mathrm{H}, \mathrm{m}), 7.74$ $(1 \mathrm{H}, \mathrm{m}), 7.85(1 \mathrm{H}, \mathrm{d}, J=8.2 \mathrm{~Hz}), 8.03(1 \mathrm{H}, \mathrm{d}, J=8.2 \mathrm{~Hz})$.

(2RS,4S,5S)- $N$-Isobutyl-5-[N-[(2RS)-2-(hydroxymethyl)-3-(1-naphthyl)propionyl]-L-norleucyl] amino-2-ethyl-4-hydroxy-7-methyloctanamide (12) To a solution of $11(43 \mathrm{mg}, 0.067 \mathrm{mmol})$ in EtOH $(1.6 \mathrm{ml})$ was added $\mathrm{NaBH}_{4}(50 \mathrm{mg}, 1.32 \mathrm{mmol})$, and the mixture was stirred for $2 \mathrm{~h}$ at room temperature. After neutralization with $3.5 \mathrm{~N}$ acetic acid $(0.2 \mathrm{ml})$, the mixture was concentrated. The residue was partitioned between AcOEt and water, and then the organic layer was washed with water and brine Drying followed by evaporation afforded $12(37.3 \mathrm{mg}, 92.8 \%)$ as a colorless solid, mp $115.0-123.0^{\circ} \mathrm{C}$. ${ }^{1} \mathrm{H}-\mathrm{NMR}\left(\mathrm{CDCl}_{3}\right) \delta: 0.60-1.02$ $(\mathrm{l} 8 \mathrm{H}, \mathrm{m}), 1.05-1.95(14 \mathrm{H}, \mathrm{m}), 2.30(1 / 2 \mathrm{H}, \mathrm{m}), 2.31(1 / 2 \mathrm{H}, \mathrm{m}), 2.88(1 \mathrm{H}$, m), $2.95-3.38(4 \mathrm{H}, \mathrm{m}), 3.40-4.10(6 \mathrm{H}, \mathrm{m}), 4.16(1 \mathrm{H}, \mathrm{m}), 5.64(1 / 2 \mathrm{H}, \mathrm{d}$, $J=7.2 \mathrm{~Hz}), 5.85-6.20(1 \mathrm{H}, \mathrm{m}), 5.22-5.35(\mathrm{l} / 2 \mathrm{H}, \mathrm{m}), 7.85(1 \mathrm{H}, \mathrm{m})$, $7.90-8.10(1 \mathrm{H}, \mathrm{m})$.

$(2 R S, 4 S, 5 S)-N$-Isobutyl-5-[N-[(2R)-2-(acetoxymethyl)-3-(1-naphthyl)propionyl]-L-norleucyl]amino-2-ethyl-4-hydroxy-7-methyloctanamide (14R) To a solution of $N-[(2 R)$-2-(hydroxymethyl)-3-(1-naphthyl)propionyl]-Lnorleucine tert-butyl ester $(13 R, 23.0 \mathrm{mg}, 0.058 \mathrm{mmol})$ in pyridine $(0.5 \mathrm{ml})$ was added acetic anhydride $(0.1 \mathrm{ml})$ at room temperature. After $3 \mathrm{~h}$, water $(0.1 \mathrm{ml})$ was added and the solution was concentrated. The residue was dissolved in AcOEt, and washed with water and brine. After evaporation, the residue was dissolved in $\mathrm{CH}_{2} \mathrm{Cl}_{2}(0.5 \mathrm{ml})$ and TFA $(0.5 \mathrm{ml})$ was added. The mixture was stirred for $2 \mathrm{~h}$ at room temperature and concentrated. The residue was dissolved in DMF $(0.5 \mathrm{ml})$, and then triethylamine $(16 \mu \mathrm{l}, 0.12 \mathrm{mmol})$, DPPA $(16 \mu 1,0.075 \mathrm{mmol})$ and a solution of AEHMA isobutylamide hydrochloride $(27 \mathrm{mg}, 0.086 \mathrm{mmol})$ and triethylamine $(16 \mu 1,0.12 \mathrm{mmol})$ in DMF $(0.8 \mathrm{ml})$ were added at $-10^{\circ} \mathrm{C}$. The mixture was stirred at $-10^{\circ} \mathrm{C}$ for $30 \mathrm{~min}$ and further stirred at $5{ }^{\circ} \mathrm{C}$ overnight. The reaction mixture was diluted with AcOEt and washed with $5 \% \mathrm{KHSO}_{4}, 4 \% \mathrm{NaHCO}_{3}$ and brine. Drying followed by evaporation and purification by flash silica gel chromatography $\left(\mathrm{CHCl}_{3}: \mathrm{MeOH}=50: 1\right)$ gave $14 R(31.8 \mathrm{mg}, 86.3 \%)$ as a colorless solid, mp 186.0-189.0 ${ }^{\circ} \mathrm{C} .{ }^{1} \mathrm{H}-\mathrm{NMR}\left(\mathrm{CDCl}_{3}\right) \delta: 0.75-1.00(18 \mathrm{H}, \mathrm{m}), 1.16$ $1.92(14 \mathrm{H}, \mathrm{m}), 2.03(3 \mathrm{H}, \mathrm{s}), 2.19(1 / 2 \mathrm{H}, \mathrm{m}), 2.29(1 / 2 \mathrm{H}, \mathrm{m}), 2.90-3.30$ $(5 \mathrm{H}, \mathrm{m}), 3.30-3.48(1 \mathrm{H}, \mathrm{m}), 3.60(1 \mathrm{H}, \mathrm{m}), 3.72-3.93(1 \mathrm{H}, \mathrm{m})$, $4.15-4.40(3 \mathrm{H}, \mathrm{m}), 5.77(1 / 2 \mathrm{H}, \mathrm{m}), 5.87(1 / 2 \mathrm{H}, \mathrm{m}), 5.98(1 / 2 \mathrm{H}, \mathrm{d}$, $J=9.8 \mathrm{~Hz}), 6.06(1 \mathrm{H}, \mathrm{m}), 6.12(1 / 2 \mathrm{H}, \mathrm{d}, J=7.7 \mathrm{~Hz}), 7.30-7.40(2 \mathrm{H}, \mathrm{m})$, $7.42-7.60(2 \mathrm{H}, \mathrm{d}, J=8.8 \mathrm{~Hz}), 7.85(1 \mathrm{H}, \mathrm{d}, J=8.8 \mathrm{~Hz}), 7.95-8.05$ $(1 \mathrm{H}, \mathrm{m})$.

$(2 R S, 4 S, 5 S)-N$-Isobutyl-5-[N-[(2S)-2-(acetoxymethyl)-3-(1-naphthyl)propionyl]-L-norleucyl]amino-2-ethyl-4-hydroxy-7-methyloctanamide (14S) The title compound was prepared from $13 S(33 \mathrm{mg}, 0.084 \mathrm{mmol})$ by a procedure similar to that described for $14 R$, and was purified by flash silica gel chromatography $\left(\mathrm{CHCl}_{3}: \mathrm{MeOH}=50: 1\right)$; yield $49.3 \mathrm{mg}(92.2 \%)$ as a colorless solid, mp 186.0-189.0 ${ }^{\circ} \mathrm{C} .{ }^{1} \mathrm{H}-\mathrm{NMR}\left(\mathrm{CDCl}_{3}\right) \delta: 0.62-1.00$ $(18 \mathrm{H}, \mathrm{m}), 1.00-1.90(14 \mathrm{H}, \mathrm{m}), 2.05(3 \mathrm{H}, \mathrm{m}), 2.10-2.22(1 / 2 \mathrm{H}, \mathrm{m})$, $2.22-2.33(1 / 2 \mathrm{H}, \mathrm{m}), 2.86-3.08(2 \mathrm{H}, \mathrm{m}), 2.08-3.20(2 \mathrm{H}, \mathrm{m}), 3.30-3.38$ $(1 \mathrm{H}, \mathrm{m}), 3.68(1 \mathrm{H}, \mathrm{m}), 3.81(1 \mathrm{H}, \mathrm{m}), 4.14(1 \mathrm{H}, \mathrm{m}), 4.25-4.42(2 \mathrm{H}, \mathrm{m})$, $7.25-7.40(2 \mathrm{H}, \mathrm{m}), 7.40-7.58(2 \mathrm{H}, \mathrm{m}), 7.72(1 \mathrm{H}, \mathrm{d}, J=9.0 \mathrm{~Hz}), 7.85$ 
$(1 \mathrm{H}, \mathrm{d}, J=9.0 \mathrm{~Hz}), 8.00(1 \mathrm{H}, \mathrm{m})$.

(2RS,4S,5S)- $N$-Isobutyl-5-[N-[(2RS)-3-benzyloxymethyl-3-(1-naphthyl)propionyl]-L-norleucyl]amino-2-ethyl-4-hydroxy-7-methyloctanamide (17) To a suspension of $9(900 \mathrm{mg}, 3.33 \mathrm{mmol})$ and $\mathrm{LiOH}(86 \mathrm{mg}, 3.50 \mathrm{mmol})$ in THF $(30 \mathrm{ml})$ was added $\mathrm{LiBH}_{4}(291 \mathrm{mg}, 13.3 \mathrm{mmol})$ at $0^{\circ} \mathrm{C}$. After being stirred at $0^{\circ} \mathrm{C}$ for $3 \mathrm{~h}$ and further stirred at room temperature overnight, the mixture was concentrated. The residue was partitioned between AcOEt and water, and the organic layer was washed with water and brine. Drying followed by evaporation and crystallization from $\mathrm{Et}_{2} \mathrm{O}$-hexane gave 2(RS)-hydroxymethyl-3-(1-naphthyl)propionic acid $(655 \mathrm{mg}, 85.4 \%)$ as a colorless powder. A solution of this acid (30 $\mathrm{mg}$, $0.13 \mathrm{mmol})$ in DMF $(1 \mathrm{ml})$ and benzyl bromide $(133 \mathrm{mg}, 0.78 \mathrm{mmol})$ were added to a suspension of $\mathrm{NaH}(60 \%$ in oil, $13 \mathrm{mg}, 0.32 \mathrm{mmol})$ in DMF $(0.5 \mathrm{ml})$ at room temperature under argon. After being stirred overnight, the mixture was poured into ice-water. The resulting mixture was extracted with AcOEt and the organic layer was washed with brine. Drying followed by evaporation and purified by preparative TLC with AcOEt-hexane (1:5) afforded 2(RS)-benzyloxymethyl-3-(1-naphthyl)propionic acid benzyl ester $(14.8 \mathrm{mg}, 27.7 \%)$ as a colorless oil. To a solution of the benzyl ester $(27.5 \mathrm{mg}, 0.067 \mathrm{mmol})$ in EtOH-water $(9: 1$, $1 \mathrm{ml}$ ) was added $2 \mathrm{~N} \mathrm{KOH}(0.17 \mathrm{ml})$. The mixture was stirred at room temperature overnight and acidified to $\mathrm{pH} 2$ with $1 \mathrm{~N} \mathrm{HCl}$. The mixture was extracted with AcOEt and the organic layer was washed with water and brine. Drying and evaporation gave $15(25.5 \mathrm{mg}$, quant.) as a pale yellow oil. ${ }^{1} \mathrm{H}-\mathrm{NMR}\left(\mathrm{CDCl}_{3}\right) \delta: 3.17(1 \mathrm{H}, \mathrm{m}), 3.34(1 \mathrm{H}, \mathrm{dd}, J=8.0$, $15.0 \mathrm{~Hz}), 3.58(1 \mathrm{H}, \mathrm{dd}, J=7.1,15.0 \mathrm{~Hz}), 3.67(2 \mathrm{H}, \mathrm{d}, J=8.0 \mathrm{~Hz}), 4.53$ $(2 \mathrm{H}, \mathrm{s}), 7.24-7.42(7 \mathrm{H}, \mathrm{m}), 7.50(2 \mathrm{H}, \mathrm{m}), 7.74(1 \mathrm{H}, \mathrm{d}, J=8.0 \mathrm{~Hz}), 7.85$ $(1 \mathrm{H}, \mathrm{m}), 8.05(1 \mathrm{H}, \mathrm{d}, J=8.0 \mathrm{~Hz})$. The title compound was prepared from $4(54 \mathrm{mg}, 0.104 \mathrm{mmol})$ and $15(25 \mathrm{mg}, 0.078 \mathrm{mmol})$ using DPPA (25.6 $\mathrm{mg}$, $0.93 \mathrm{mmol}$ ) by a procedure similar to that described for $\mathbf{5}$, and was purified by preparative TLC $\left(\mathrm{CHCl}_{3}: \mathrm{MeOH}=20: 1\right)$; yield $38.0 \mathrm{mg}$ $(70.8 \%)$ as a colorless solid, mp $129.0-131.0{ }^{\circ} \mathrm{C} .{ }^{1} \mathrm{H}-\mathrm{NMR}\left(\mathrm{CDCl}_{3}\right) \delta$ : $0.75-1.00(18 \mathrm{H}, \mathrm{m}), 1.02-1.95(14 \mathrm{H}, \mathrm{m}), 2.18(1 / 2 \mathrm{H}, \mathrm{m}), 2.32(1 / 2 \mathrm{H}$, $\mathrm{m}), 2.75-4.65(12 \mathrm{H}, \mathrm{m}), 7.20-7.40(7 \mathrm{H}, \mathrm{m}), 7.50(2 \mathrm{H}, \mathrm{m}), 7.72(1 \mathrm{H}, \mathrm{d}$, $J=8.0 \mathrm{~Hz}), 7.85(1 \mathrm{H}, \mathrm{m}), 8.05(1 \mathrm{H}, \mathrm{m})$.

$N$-[2(S)-Ethylsulfonyl-3-(1-naphthyl)propionyl $]-\left(N^{\text {im }}\right.$-trityl)-L-histidine Methyl Ester (26) To a solution of 2(R)-hydroxymethyl-3-(1-naphthyl)propionic acid (25) $(1.26 \mathrm{~g}, 5.47 \mathrm{mmol}), N^{\text {im }}$-trityl-L-histidine methyl ester $(2.7 \mathrm{~g}, 6.56 \mathrm{mmol})$ and HOBT $(1.09 \mathrm{~g}, 7.11 \mathrm{mmol})$ in DMF $(15 \mathrm{ml})$ was added $\mathrm{DCC}(1.47 \mathrm{~g}, 7.11 \mathrm{mmol})$ at $-10^{\circ} \mathrm{C}$. The reaction mixture was stirred at $-5^{\circ} \mathrm{C}$ for $2 \mathrm{~h}$ and further stirred at $5^{\circ} \mathrm{C}$ overnight. The precipitate was filtered off and the filtrate was concentrated. The residue was dissolved in AcOEt and washed with $5 \% \mathrm{KHSO}_{4}, 4 \% \mathrm{NaHCO}_{3}$ and brine. Drying followed by evaporation and purification by silica gel chromatography (AcOEt: hexane $=4: 1$ ) afforded $N$-acyl derivative $(3.20 \mathrm{~g}, 93.8 \%)$ as a colorless solid, $\mathrm{mp} 194.0-201.0^{\circ} \mathrm{C},[\alpha]_{\mathrm{D}}^{20}+42.3^{\circ}$ $\left(c=1.02, \mathrm{CHCl}_{3}\right) .{ }^{1} \mathrm{H}-\mathrm{NMR}\left(\mathrm{CDCl}_{3}\right) \delta: 2.87(2 \mathrm{H}, \mathrm{m}), 3.12(1 \mathrm{H}, \mathrm{dd}$, $J=7.4,14.6 \mathrm{~Hz}), 3.29(1 \mathrm{H}, \mathrm{dd}, J=3.7,14.6 \mathrm{~Hz}), 3.53(3 \mathrm{H}, \mathrm{s}), 3.74(2 \mathrm{H}$, $\mathrm{m}), 3.85(1 \mathrm{H}, \mathrm{dd}, J=8.7,11.7 \mathrm{~Hz}), 4.85(1 \mathrm{H}, \mathrm{m}), 6.49(1 \mathrm{H}, \mathrm{d}, J=1.5 \mathrm{~Hz})$, $6.72(1 \mathrm{H}, \mathrm{d}, J=7.8 \mathrm{~Hz}), 7.04-7.12(6 \mathrm{H}, \mathrm{m}), 7.30-7.42(12 \mathrm{H}, \mathrm{m}), 7.47$ $(2 \mathrm{H}, \mathrm{m}), 7.70(1 \mathrm{H}, \mathrm{m}), 7.83(1 \mathrm{H}, \mathrm{m}), 8.03(1 \mathrm{H}, \mathrm{m})$. To a solution of $N$-acylhistidine derivative $(1.87 \mathrm{~g}, 3.00 \mathrm{mmol})$ in pyridine $(15 \mathrm{ml})$ was added $p$-toluenesulfonyl chloride $(1.16 \mathrm{~g}, 6.00 \mathrm{mmol})$. The solution was stirred at room temperature overnight and concentrated. The residue was dissolved in AcOEt and washed with $5 \% \mathrm{KHSO}_{4}, 4 \% \mathrm{NaHCO}_{3}$, water and brine. Drying followed by evaporation and purification by silica gel chromatography (AcOEt: hexane $=3: 1)$ afforded the tosylate $(1.94 \mathrm{~g}$, $83.1 \%$ ) as a pale yellow amorphous. To a suspension of ethyl mercaptan $(285 \mu \mathrm{l}, 3.86 \mathrm{mmol})$ and $\mathrm{NaH}(60 \%$ in oil, $62 \mathrm{mg}, 1.54 \mathrm{mmol})$ was added a solution of the tosylate $(66 \mathrm{mg}, 0.77 \mathrm{mmol})$ in DMF $(4 \mathrm{ml})$ at $-10^{\circ} \mathrm{C}$. After being stirred at room temperature for $1 \mathrm{~h}$, the mixture was diluted with AcOEt and washed with water and brine. Drying and evaporation gave a yellow residue. The residue was dissolved in $\mathrm{MeOH}(20 \mathrm{ml})$ and $30 \% \mathrm{H}_{2} \mathrm{O}_{2}(2 \mathrm{ml})$ and $\mathrm{Na}_{2} \mathrm{WO}_{4}(100 \mathrm{mg})$ were added. The mixture was stirred at room temperature overnight and concentrated. The residue was dissolved in AcOEt and washed with water and brine. Drying followed by evaporation and purification by silica gel chromatography $\left(\mathrm{CHCl}_{3}: \mathrm{MeOH}=100: 1\right)$ afforded $26(378 \mathrm{mg}, 70.1 \%)$ as a colorless oil, $[\alpha]_{\mathrm{D}}^{20}+32.3^{\circ}\left(c=1.07, \mathrm{CHCl}_{3}\right)$. IR (neat): 3352, $1749,1677 \mathrm{~cm}^{-1}$. ${ }^{1} \mathrm{H}-\mathrm{NMR}\left(\mathrm{CDCl}_{3}\right) \delta: 1.10(3 \mathrm{H}, \mathrm{t}, J=7.4 \mathrm{~Hz}), 2.62-3.00(5 \mathrm{H}, \mathrm{m})$, $3.10-3.25(2 \mathrm{H}, \mathrm{m}), 3.35-3.55(1 \mathrm{H}, \mathrm{m}), 3.44(3 \mathrm{H}, \mathrm{s}), 3.60-3.72(1 \mathrm{H}$, $\mathrm{m}), 4.62(1 \mathrm{H}, \mathrm{m}), 6.43(1 \mathrm{H}, \mathrm{s}), 6.90-7.04(6 \mathrm{H}, \mathrm{m}), 7.14-7.44(11 \mathrm{H}$, $\mathrm{m}), 7.51(1 \mathrm{H}, \mathrm{d}, J=7.8 \mathrm{~Hz}), 7.61(1 \mathrm{H}, \mathrm{dd}, J=1.2,7.8 \mathrm{~Hz}), 7.66-7.72$ $(1 \mathrm{H}, \mathrm{m}), 7.94-8.02(1 \mathrm{H}, \mathrm{m})$. FAB-MS $m / z:[\mathrm{M}+\mathrm{H}]^{+}$Calcd for $\mathrm{C}_{42} \mathrm{H}_{42} \mathrm{~N}_{3} \mathrm{O}_{5} \mathrm{~S}: 700.2845$. Found: 700.2853 .
$(2 R S, 4 S, 5 S)-N$-Isobutyl-5-[N-[(2S)-2-ethylsulfonylmethyl-3-(1-naphthyl)propionyl]-L-histidyl] amino-2-ethyl-4-hydroxy-7-methyloctanamide (27) To a solution of $26(53 \mathrm{mg}, 0.076 \mathrm{mmol})$ in $\mathrm{MeOH}$-water (10:1, $1.5 \mathrm{ml})$ was added $1 \mathrm{~N} \mathrm{KOH}($ EtOH $:$ water $=10: 1,0.38 \mathrm{ml})$ and the mixture was stirred at room temperature for $1 \mathrm{~h}$. After acidification with $1 \mathrm{~N} \mathrm{HCl}$, the mixture was diluted with AcOEt and washed with water and brine. Drying and evaporation gave the corresponding acid $(49.4 \mathrm{mg}$, $95.1 \%)$ as a pale yellow oil. This acid $(33 \mathrm{mg}, 0.05 \mathrm{mmol})$ was condensed with AEHMA isobutylamide (3) $(21 \mathrm{mg}, 0.06 \mathrm{mmol})$ using DPPA by the usual method to afford $N^{\text {im }}$-trityl $27(37.5 \mathrm{mg}, 81.7 \%)$ as a colorless solid. $N^{\text {im }}$-trityl $27(28.6 \mathrm{mg}, 0.037 \mathrm{mmol})$ was dissolved in $\mathrm{CH}_{2} \mathrm{Cl}_{2}$ $(0.5 \mathrm{ml})$ and TFA $(0.1 \mathrm{ml})$ was added. The mixture was stirred at room temperature for $3 \mathrm{~h}$ and concentrated. The residue was purified by silica gel chromatography $\left(\mathrm{CHCl}_{3}: \mathrm{MeOH}=20: 1\right)$ to afford 27 (16.8 mg, $87.3 \%)$ as a colorless solid, mp $108.0-114.0^{\circ} \mathrm{C} .{ }^{1} \mathrm{H}-\mathrm{NMR}\left(\mathrm{CDCl}_{3}\right) \delta$ : $0.56-1.00(14 \mathrm{H}, \mathrm{m}), 1.10-1.81(12 \mathrm{H}, \mathrm{m}), 2.24(1 / 2 \mathrm{H}, \mathrm{m}), 2.70-3.28$ $(9 \mathrm{H}, \mathrm{m}), 3.40-3.88(5 \mathrm{H}, \mathrm{m}), 4.68(1 / 2 \mathrm{H}, \mathrm{m}), 4.78(1 / 2 \mathrm{H}, \mathrm{m}), 6.44(1 \mathrm{H}$, br), $6.56(1 \mathrm{H}, \mathrm{br}), 6.94(1 \mathrm{H}, \mathrm{m}), 7.22-7.40(2 \mathrm{H}, \mathrm{m}), 7.40-7.55(3 \mathrm{H}, \mathrm{m})$, $7.72(1 \mathrm{H}, \mathrm{d}, J=7.9 \mathrm{~Hz}), 7.82(1 \mathrm{H}, \mathrm{m}), 8.02(1 \mathrm{H}, \mathrm{m})$.

(2R)-2-(1-Naphthyl)methyl-1,3-propanediol 1-Acetate (29) The suspension of 2-(1-naphthyl)methyl-1,3-propanediol $(20 \mathrm{~g}, 92.6 \mathrm{mmol})$ in vinyl acetate $(50 \mathrm{ml})$ was added lipase $\mathrm{P}(3 \mathrm{~g})$, and the mixture was stirred at room temperature for $4.5 \mathrm{~h}$ and further stirred at $30^{\circ} \mathrm{C}$ for $2 \mathrm{~h}$. Another portion of lipase $\mathrm{P}(1.2 \mathrm{~g})$ was added and stirred at $8^{\circ} \mathrm{C}$ for $2 \mathrm{~d}$. Lipase $\mathrm{P}$ was filtered off and the filtrate was concentrated. The residue was purified by silica gel chromatography (AcOEt: hexane $=1: 2$ ) to afford 29 $(22.2 \mathrm{~g}, 93.1 \%)$ as a colorless oil, $[\alpha]_{\mathrm{D}}^{20}+35.7^{\circ}\left(c=1.03, \mathrm{CHCl}_{3}\right)$. ${ }^{1} \mathrm{H}-\mathrm{NMR}\left(\mathrm{CDCl}_{3}\right) \delta: 2.00(3 \mathrm{H}, \mathrm{t}, J=5.7 \mathrm{~Hz}), 2.12(3 \mathrm{H}, \mathrm{s}), 2.32(1 \mathrm{H}, \mathrm{m})$, $3.07(1 \mathrm{H}, \mathrm{dd}, J=7.6,13.7 \mathrm{~Hz}), 3.18(1 \mathrm{H}, \mathrm{dd}, J=7.6,13.7 \mathrm{~Hz}), 3.54-3.72$ $(2 \mathrm{H}, \mathrm{m}), 4.18(1 \mathrm{H}, \mathrm{dd}, J=6.7,11.4 \mathrm{~Hz}), 4.24(1 \mathrm{H}, \mathrm{dd}, J=6.7,11.4 \mathrm{~Hz})$, $7.30-7.55(4 \mathrm{H}, \mathrm{m}), 7.75(1 \mathrm{H}, \mathrm{d}, J=7.8 \mathrm{~Hz}), 7.86(1 \mathrm{H}, \mathrm{m}), 8.04(1 \mathrm{H}, \mathrm{m})$. The enantiomer excess was determined to be $86 \%$ ee by HPLC analysis using a column packed with Chiralcel OC (iso- $\mathrm{PrOH}:$ hexane $=1: 9$, flow rate; $0.8 \mathrm{ml} / \mathrm{min}) . t_{\mathrm{R}}, 2 R$ compound, $31.4 \mathrm{~min} ; 2 S$ compound, $35.4 \mathrm{~min}$.

(2S)-2-(1-Naphthyl)methyl-1- $O$-methoxymethyl-1,3-propanediol (30) To a solution of $29(19.1 \mathrm{~g}, 74.0 \mathrm{mmol})$ and diisopropylethylamine $(28.7 \mathrm{~g}$, $222.1 \mathrm{mmol})$ in $\mathrm{CH}_{2} \mathrm{Cl}_{2}(100 \mathrm{ml})$ was added chloromethyl methyl ether $(17.9 \mathrm{~g}, 222.1 \mathrm{mmol})$, and the solution was stirred at room temperature overnight. After concentration, the residue was dissolved in AcOEt and the solution was washed with $1 \mathrm{~N} \mathrm{HCl}$, saturated $\mathrm{NaHCO}_{3}$, water and brine. Drying and evaporation gave pale yellow oil $(21.3 \mathrm{~g})$. To a solution of the residue in $\mathrm{MeOH}-$ water $(4: 1,250 \mathrm{ml})$ was added $2 \mathrm{M} \mathrm{K}_{2} \mathrm{CO}_{3}$ $(70 \mathrm{ml})$, and the mixture was stirred at room temperature for $2 \mathrm{~d}$. The mixture was concentrated and the residue was partitioned between AcOEt and water. After washing the organic layer with water and brine, drying and evaporation gave $30(17.6 \mathrm{~g}, 91.4 \%),[\alpha]_{\mathrm{D}}^{20}-20.7^{\circ}(c=0.98$, $\left.\mathrm{CHCl}_{3}\right) .{ }^{1} \mathrm{H}-\mathrm{NMR}\left(\mathrm{CDCl}_{3}\right) \delta: 2.25(\mathrm{lH}, \mathrm{m}), 2.30(\mathrm{lH}, \mathrm{m}), 3.14(2 \mathrm{H}, \mathrm{dd}$, $J=2.9,7.1 \mathrm{~Hz}), 3.40(3 \mathrm{H}, \mathrm{s}), 3.60-3.85(4 \mathrm{H}, \mathrm{m}), 4.61$ and $4.67(2 \mathrm{H}$, $\mathrm{ABq}, J=6.1 \mathrm{~Hz}), 7.35(2 \mathrm{H}, \mathrm{m}), 7.50(2 \mathrm{H}, \mathrm{m}), 7.75(1 \mathrm{H}, \mathrm{d}, J=8.9 \mathrm{~Hz})$, $7.87(1 \mathrm{H}, \mathrm{d}, J=8.9 \mathrm{~Hz}), 8.07(1 \mathrm{H}, \mathrm{d}, J=8.9 \mathrm{~Hz})$. The enantiomer excess was determined to be $86 \%$ ee by HPLC analysis using a column packed with Chiralcel OC (iso-PrOH : hexane $=1: 19$; flow rate, $0.8 \mathrm{ml} / \mathrm{min}$ ). $t_{\mathrm{R}}$, $2 S$-compound, $19.8 \mathrm{~min}$; $2 R$-compound, $17.5 \mathrm{~min}$.

(2R)-2-Hydroxymethyl-3-(1-naphthyl)propionic Acid (25) To a solution of $30(17.5 \mathrm{~g}, 67.3 \mathrm{mmol})$ in acetone $(350 \mathrm{ml})$ was added Jones reagent $(30 \mathrm{ml})$ at $0^{\circ} \mathrm{C}$ over $30 \mathrm{~min}$, and the mixture was stirred at $0^{\circ} \mathrm{C}$ for $2 \mathrm{~h}$. iso- $\mathrm{PrOH}$ was added and concentrated. The residue was dissolved in THF $(200 \mathrm{ml})$ and $6 \mathrm{~N} \mathrm{HCl}(200 \mathrm{ml})$ was added. The mixture was stirred at $50^{\circ} \mathrm{C}$ for $1.5 \mathrm{~h}$ and concentrated. The residue was dissolved in AcOEt and the solution was extracted with saturated $\mathrm{NaHCO}_{3}$. The extract was acidified with $6 \mathrm{~N} \mathrm{HCl}$ and extracted with AcOEt. Drying followed by evaporation and recrystallization from benzene gave $25(7.8 \mathrm{~g}, 50.2 \%)$ as a pale brown powder, $\mathrm{mp} 116.5-118.0^{\circ} \mathrm{C},[\alpha]_{\mathrm{D}}^{20}+33.3^{\circ} \quad(c=1.02$, $\left.\mathrm{CHCl}_{3}\right) .{ }^{1} \mathrm{H}-\mathrm{NMR}\left(\mathrm{CDCl}_{3}\right) \delta: 3.08(1 \mathrm{H}, \mathrm{m}), 3.30(1 \mathrm{H}, \mathrm{dd}, J=9.7$, $14.1 \mathrm{~Hz}), 3.65(1 \mathrm{H}, \mathrm{dd}, J=5.3,14.0 \mathrm{~Hz}), 3.75(1 \mathrm{H}, \mathrm{dd}, J=6.1,11.3 \mathrm{~Hz})$, $3.74(1 \mathrm{H}, \mathrm{dd}, J=3.9,11.3 \mathrm{~Hz})$. The enantiomer excess was determined to be $96 \%$ ee by HPLC analysis using a packed column with Senshu Pak. Silica gel $1151 \mathrm{~N}$ (hexane: $\mathrm{AcOEt}=1: 1$ ) after coupling with L-norleucine. $t_{\mathrm{R}}, 13 R, 4.70 \mathrm{~min} ; 13 S, 7.58 \mathrm{~min}$.

$N$-[(2R)-2-Hydroxymethyl-3-(1-naphthyl)propionyl]-L-norleucine tertButyl Ester (13R) The title compound was prepared from 25 (3.0 g, $13.0 \mathrm{mmol})$ and L-norleucine tert-butyl ester $(2.68 \mathrm{~g}, 14.3 \mathrm{mmol})$ by DCC-HOBT method, and was recrystallization from AcOEt-hexane; yield $4.57 \mathrm{~g}(88.1 \%)$ as colorless needles, $\mathrm{mp} 92.0-93.0^{\circ} \mathrm{C},[\alpha]_{\mathrm{D}}^{20}+50.9^{\circ}$ $\left(c=1.04, \mathrm{CHCl}_{3}\right) .{ }^{1} \mathrm{H}-\mathrm{NMR}\left(\mathrm{CDCl}_{3}\right) \delta: 0.86(3 \mathrm{H}, \mathrm{t}, J=5.6 \mathrm{~Hz}), 1.00$ 
$1.40(4 \mathrm{H}, \mathrm{m}), 1.42(9 \mathrm{H}, \mathrm{s}), 1.78(1 \mathrm{H}, \mathrm{m}), 2.70-2.85(2 \mathrm{H}, \mathrm{m}), 3.32(1 \mathrm{H}$, $\mathrm{dd}, J=7.9,13.2 \mathrm{~Hz}), 3.50(1 \mathrm{H}, \mathrm{dd}, J=7.5,13.2 \mathrm{~Hz}), 3.81(2 \mathrm{H}, \mathrm{m}), 4.37$ $(1 \mathrm{H}, \mathrm{m}), 6.12(1 \mathrm{H}, \mathrm{d}, J=7.6 \mathrm{~Hz}), 7.38(2 \mathrm{H}, \mathrm{d}, J=4.8 \mathrm{~Hz}), 7.51(2 \mathrm{H}, \mathrm{m})$, $7.73(1 \mathrm{H}, \mathrm{t}, J=4.3 \mathrm{~Hz}), 7.86(1 \mathrm{H}, \mathrm{d}, J=8.9 \mathrm{~Hz}), 8.05(1 \mathrm{H}, \mathrm{d}, J=8.9 \mathrm{~Hz})$.

Bioavailability in Rats Compound 20 dissolved in DMSO-saline (1: 19, for i.v.) or in DMSO-water (1:19, for p.o.) was injected into the tail vein at a dose of $0.35 \mathrm{mg} / \mathrm{ml} / \mathrm{kg}$ (i.v.) or given into the stomach at $8.4 \mathrm{mg} / \mathrm{ml} / \mathrm{kg}$ (p.o.) using an esophageal sound, to unrestrained conscious rats with cervical cannula. Blood samples were collected through the cervical cannula into EDTA-containing glass tubes and centrifuged. Then a methanol extract of plasma (after dryness) was subjected to the PRA inhibition assay, which was the same as described previously. ${ }^{1)}$ The percent inhibition of human PRA was converted to the plasma concentration of $\mathbf{2 0}$ using a standard curve constructed with the known concentrations of $\mathbf{2 0}$ dissolved in control rat plasma.

The areas under the plasma concentration-time curve (AUC) were calculated by using the trapezoidal rule, and the bioavailability was calculated by the following equation:

bioavailability $(\%)=\left(\mathrm{AUC}_{\text {p.o. }} / \mathrm{AUC}_{\mathrm{i} . \mathrm{v} .}\right) \times\left(\right.$ dose $\left._{\mathrm{i} . \mathrm{v} .} / \mathrm{dose}_{p . o .}\right) \times 100$

References and Notes

1) Part I: S. Atsuumi, M. Nakano, Y. Koike, S. Tanaka, K Matsuyama, M. Nakano and H. Morishima, Chem. Pharm. Bull., 40, 364 (1992).

2) a) J. Boger, Trans. Pharmacol. Sci., 8, 370 (1987); b) W. J. Greenlee, Pharm. Res., 4, 364 (1987); c) W. J. Greenlee, Med., Res., Rev., 10, $173(1990) ; d)$ W. J. Greenlee and A. E. Weber, $D N \& P, 4,332$ (1991); e) T. D. Ocain and M. Abou-Gharbia, Drugs of the Future, 16, 37 (1991), and references cited therein.

3) While this work was in progress, a number of renin inhibitors having effective N-terminal sequences were reported: a) P. Bühlmayer, A. Caselli, W. Fuhrer, R. Göschke, V. Rasetti, H. Rüeger, J. L. Stanton, L. Criscione and J. M. Wood, J. Med. Chem., 31, 1839 (1988); b) J. J. Plattner, P. A. Marcotte, H. D. Kleinert, H. H Stein, J. Greer, G. Bolis, A. K. L. Fung, B. A. Bopp, J. R. Luly, H. L. Sham, D. J. Kempf, S. H. Rosenberg, J. F. Dellaria, B. De, I Merits and T. J. Perum, ibid., 31, 2277 (1988); c) K. lizuka, T. Kamijo, T. Kubota, K. Akabane, H. Umeyama and Y. Kiso, ibid., 31, 701 (1988); d) H. D. Kleinert, J. R. Luly, A. Marcotte, T. J. Perum, J. J. Plattner and H. Stein, FEBS Lett., 230, 38 (1988); e) G. J. Hanson, J. S. Baran, H. S. Loerie, M. A. Russell, S. J. Sarussi, K. Williams, M. Babler, S. E. Bittner, S. E. Papaioannou, P.-C. Yang and G. M. Walsh, Biochem. Biophys. Res. Commun., 160 1 (1989); f) T. Nishi, M. Sakurai, S. Sato, M. Kataoka and Y. Morisawa, Chem. Pharm. Bull., 37, 2200 (1989); g) S. H. Rosenberg, K. W. Woods, H. L. Sham, H. D. Kleinert, D. L. Martin, H. Stein, J. Cohen, D. A. Egan, B. Bopp, I. Merits, K. W. Garren, D. J. Hoffman and J. J. Plattner, J. Med. Chem., 33, 1962 $(1990) ; h)$ T. Nishi, Y. Morisawa, Y. Iijima, H. Koike and Y. Yabe, J. Chem. Soc., Chem. Commun., 1990, 1672; i) S. Thaisrivongs, D. T. Pals, D. W. DuCharme, S. R. Turner, G. L. DeGraaf, J. A. Lawson, S. J. Couch and M. V. Williams, J. Med. Chem., 34, 633 (1991).

4) a) M. Nakano, S. Atsuumi, Y. Koike, S. Tanaka, H. Funabashi, J.
Hashimoto, M. Ohkubo and H. Morishima, Bull. Chem. Soc. Jpn., 63, 2224 (1990); b) Idem, Chem. Lett., 1990, 505.

5) J. Hiratake, K. Shibata, N. Baba and J. Oda, Synthesis, 1988, 278.

6) S. Atsuumi, M. Nakano, Y. Koike, S. Tanaka, M. Ohkubo, T. Yonezawa, H. Funabashi, J. Hashimoto and H. Morishima, Tetrahedron Lett., 31, 1601 (1990).

7) a) M. D. Castaing, B. D. Jeso, S. Drouillard and B. Maillard, Tetrahedron Lett., 28, 953 (1987); b) Y. F. Wang, J. J. Lalonde, M. Momongan, D. E. Bergbreiter and C. H. Wong, J. Am. Chem. Soc., 110, 7200 (1988).

8) A similar reaction has been reported independently, but the absolute configuration was not determined: K. Tsuji, Y. Terao and K. Achiwa, Tetrahedron Lett., 30, 6189 (1989).

9) The absolute configuration was determined by comparison of the measured optical rotations to that of the authentic compound synthesized by the method of D. A. Evans: see ref. 4.

10) Recently, renin inhibitors which had no substituent at this position have been reported. They had the hydroxyethylene isostere at the $\mathbf{P}_{1}-\mathbf{P}_{1}$, site and a $\beta$-aspartyl residue at the $\mathbf{P}_{2}$ site: $\mathbf{S}$. Thaisrivongs, B. Mao, D. T. Pals, S. R. Turner and L. T. Kroll, J. Med. Chem., 33, 1337 (1990).

11) Unpublished data

12) The renin inhibitors having sulfonemethylene isostere at N-terminus have been reported by Bühlmayer et al. independently: see ref. $3 a$.

13) A. R. Sielecki, K. Hayakawa, M. Fujinaga, M. E. P. Murphy, M. Fraser, A. K. Muir, C. T. Carilli, J. A. Lewicki, J. D. Baxter, M. N. G. James, Science, 243, 1346 (1989).

14) V. Dhanaraj, C. G. Dealwis, C. Frazao, M. Badasso, B. L. Sibanda, I. J. Tickle, J. B. Cooper, H. P. C. Driessen, M. Newman, C. Aguilar, S. P. Wood, T. L. Blundell, P. M. Hobart, K. F Geoghegan, M. J. Ammirati, D. E. Danley, B. A. O'Connor and D. J. Hoover, Nature (London), 357, 466 (1992).

15) A. R. Sielecki, A. A. Fedorov, A. Boodhoo, N. S. Andreeva and M. N. G. James, J. Mol. Biol., 214, 143 (1990); 4PEP in Protein Data Bank at Brookhaven National Laboratory. ${ }^{20)}$

16) BIOCES[E]: Molecular Modeling System on Engineering Work Station; NEC Corporation, Tokyo, Japan.

17) K. Suguna, E. A. Padlan, C. W. Smith, W. D. Carlxon and D. R. Davies, Proc. Natl. Acad. Sci. U.S.A., 84, 7009 (1987); 3APR in Protein Data Bank at Brookhaven National Laboratory, ${ }^{20)}$

18) K. Lizuka, T. Kamijo, H. Harada, K. Akahane, T. Kubota, Y. Etoh, I. Shimaoka, A. Tsubaki, M. Murakami, T. Yamaguchi, A. Iyobe H. Umeyama and Y. Kiso, Chem. Pharm. Bull., 38, 2487 (1990).

19) S. H. Rosenberg, H. D. Kleinert, H. H. Stein, D. L. Martin, M. A. Chekal, J. Cohen, D. A. Egan, K. A. Tricarico and W. R. Baker, J. Med. Chem., 34, 469 (1991).

20) a) F. C. Bernstein, T. F. Koetzle, G. J. B. Williams, E. F. Meyer, Jr., M. D. Brice, J. R. Rodgers, O. Kennard, T. Shimanouchi and M. Tasumi, J. Mol. Biol., 112, 535 (1977); b) E. E. Abola, F. C. Bernstein, S. H. Bryant, T. F. Koetzle and J. Weng, "Protein Data Bank" in Crystallographic Databases-Information Content, Software systems, Scientific Applications, eds. by F. H. Allen, F. Bergerhoff and R. Sievers, Data Commission of the Int'l Union of Crystallography, Bonn, Cambridge, Chester, 1987, pp. 107-132. 